\title{
ANALISIS MUATAN NILAI-NILAI KARAKTER PADA BUKU SISWA KELAS IV SEKOLAH DASAR TEMA INDAHNYA KEBERSAMAAN
}

\author{
Muhammad Habib Ridwan; Alif Mudiono \\ PP3 Jl. Ir. Soekarno No.1 Blitar; KSDP FIP UM \\ email: ridwanpgsd76@gmail.com
}

\begin{abstract}
Abstrak: Penelitian ini untuk menganalisis nilai karakter dalam buku siswa tema indahnya kebersamaan kelas IV SD yang di dalamnya mencakup (1) religius, (2) jujur, (3) disiplin, (4) santun, (5) percaya diri, (6) peduli, dan (7) tanggung jawab. Penelitian ini menggunakan pendekatan kualitatif dengan instrumen berupa lembar perekam data. Sumber data penelitian ini berupa buku tema "Indahnya Kebersamaan di Kelas V SD". Hasil penelitian menunjukkan bahwa pengembangan nilai karakter religius, percaya diri dan peduli sudah dilakukan dengan cukup baik. Sementara itu, nilai karakter jujur, disiplin, santun, dan tanggung jawab masih perlu dikembangkan. Disarankan bagi peneliti selanjutnya untuk menganalisis muatan nilai-nilai karakter pada tema-tema yang lain sehingga nilai-nilai karakter yang dikembangkan dapat teridentifikasi secara dengan jelas sesuai dengan nilai-nilai karakter yang dikembangkan.
\end{abstract}

Kata kunci: nilai-nilai karakter, buku siswa SD, dan tematik terpadu.

Perbedaan antara seseorang dengan yang lain dapat dilihat dari karakter yang dimilikinya. Philips (dalam Muslich, 2011:70) mengemukakan bahwa "Karakter adalah kumpulan tata nilai yang menuju suatu sistem yang melandasi pemikiran, sikap, dan perilaku yang ditampilkan". Nilai-nilai karakter penting ditanamkan dan dikembangkan pada siswa sejak usia prasekolah. Nilai karakter tersebut dapat bermanfaat bagi siswa untuk menjalalani hidup bermasyarakat di masa depan. Penanaman nilai karakter dapat dilakukan melalui lingkungan. Salah satu lingkungan yang tepat untuk menanamkan nilai-nilai karakter adalah sekolah. Menurut Megawangi (dalam Kesuma, 2011: 5) pendidikan karakter sebagai upaya untuk mendidik siswa agar dapat mengambil suatu kepurusan dan kebijakan dalam mempraktikkan dalam kehidupan sehari-hari, sehingga mereka dapat memberikan kontribusi yang positif pada lingkungannya. Dalam hal ini, nilai-nilai karakter yang ditanamkan pada diri siswa diharapkan akan membentuk suatu karakter yang baik.

Dalam Peraturan Menteri Pendidikan dan Kebudayaan No. 21 (2016) Tentang Standar Isi Pendidikan Dasar dan Menengah menjelaskan bahwa karakter yang harus tertanam pada diri siswa tingkat pendidikan dasar terdapat dalam kompetensi sikap spiritual dan kompetensi sikap sosial. Nilai-nilai karakter tersebut yaitu religius, jujur, disiplin, santun, percaya diri, peduli, dan tanggung jawab. Penanaman nilai-nilai karakter tersebut dapat dilakukan melalui lingkungan sekolah oleh guru dan bekerjasama dengan orang tua siswa.

Penanaman nilai-nilai karakter dapat dilakukan melalui kegiatan pembelajaran.Pada kegiatan pembelajaran dapat menggunakan bahan ajar sebagai sumber belajar siswa. Bahan ajar yang digunakan dalam Kurikulum 
2013 adalah bahan ajar cetak yaitu buku ajar. Camblis dan Calfee (dalam Muslich, 2010: 50) menjelaskan bahwa buku ajar memiliki kekuatan yang luar biasa besar terhadap perubahan otak siswa dan buku ajar dapat memengaruhi pengetahuan anak dan nilainilai tertentu. Sesuai dengan pendapat tersebut buku ajar dapat digunakan sebagai sarana untuk belajar tentang pengetahuan dan nilainilai karakter. Dalam kegiatan pembelajaran buku ajar dapat digunakan sebagai sumber belajar siswa tentang nilai-nilai karakter yang bermanfaat untuk masa depannya.

Peraturan Menteri Pendidikan Nasional No. 2 (2008) Tentang Buku menyebutkan bahwa buku ajar memuat materi pembelajaran dalam rangka peningkatan keimanan, ketakwaan, akhlak mulia, dan kepribadian, penguasaan ilmu pengetahuan dan teknologi, peningkatan kepekaan dan kemampuan estetis, peningkatan kemampuan kinestetis dan kesehatan yang disusun berdasarkan standar nasional pendidikan. Berdasarkan kutipan tersebut, buku ajar tidak hanya untuk menanamkan materi ilmu pengetahuan saja kepada siswa, namun juga materi keimanan, ketakwaan, ahklak mulia, dan kepribadian yang berkatitan erat dengan penanaman nilai-nilai karakter. Jadi, buku ajar dapat digunakan dalam kegiatan pembelajaran untuk menanamkan nilai-nilai karakter pada siswa.

Bahan ajar yang digunakan pada Kurikulum 2013 adalah bahan ajar cetak yang terdiri dari buku guru dan buku siswa. Buku guru berisi kegiatan yang sama dengan buku siswa, namun dengan komponen yang berbeda. Secara umum, buku guru berisi rincian kegiatan yang akan dilakukan dan bahan apa saja yang perlu dipersiapkan untuk melaksanakan sebuah pembelajaran. Dalam hal ini, buku siswa merupakan pedoman pembelajaran bagi siswa dalam mengikuti proses pembelajaran di sekolah dasar. Buku siswa dilengkapi dengan gambar-gambar yang menarik, cerita pendek, lagu-lagu daerah, permainan-permainan yang menyenangkan, materi pembelajaran yang sederhana, serta lembar kerja yang menarik. Peraturan Menteri Pendidikan dan Kebudayaan No. 08 (2016) Tentang Buku dijelaskan bahwa "Uraian materi harus dapat mengembangkan pengetahuan, keterampilan, dan sikap positif siswa". Ketiga aspek tersebut harus dikembangkan di dalam buku siswa agar tujuan pembelajaran sehingga dapat mencapai.

Buku siswa untuk kelas IV Sekolah Dasar mencakup 9 tema, yakni (1) indahnya kebersamaan; (2) selalu berhemat energ;, (3) peduli terhadap mahluk hidup; (4) berbagai pekerjaan; (5) pahlawanku; (6) indahnya negeriku; (7) cita-citaku; (8) tempat tinggalku; dan (9) makanan sehat dan bergizi. Tema indahnya kebesamaan mempunyai peran penting dalam upaya penanaman sikap menghargai keberagaman atau toleransi pada siswa. Masyarakat Indonesia yang beragam dari berbagai suku, ras dan agama, membutuhkan sikap toleransi untuk menjaga keutuhan. Meskipun kenyataan munculnya konflik di berbagai daerah akibat perbedaan tersebut. Hal itu menjadi isyarat pentingnya mengajarkan sikap menghargai keberagaman atau toleransi kepada siswa.

Pada saat ini banyak permasalahan tentang intoleransi di masyarakat. Mulai dari perbedaan penafsiran ajaran agama, perbedaan pandangan politik, munculnya gerakan-gerakan radikalisme, banyaknya aksi kekerasan, dan sebagainya. Intoleransi di masyarakat dapat dicegah melalui pendidikan. Memperkenalkan tentang keragaman kepada siswa dapat memupuk jiwa toleransi siswa agar lebih memandang perbedaan yang ada secara lebih bijak. Mengajarkan pada siswa bahwa meskipun orang lain memiliki agama atau suku yang berbeda, manusia sebenarnya sama dan tidak boleh dibeda-bedakan.

Pada tahun 2016 telah dilakukan revisi pada buku ajar Kurikulum 2013 untuk kelas IV. Salah satu buku ajar yang telah direvisi adalah buku tema Indahnya Kebersamaan. Buku siswa tema Indahnya Kebersamaan terdiri dari 3 subtema. Masing-masing subtema terdiri dari 6 pembelajaran. Adanya revisi tersebut diharapkan kualitas buku semakin baik, dan 
keempat kompetensi yang harus ditanamkan dapat muncul secara merata disemua bagian. Oleh sebab itu, perlu dilakukan analisis yang terfokus pada buku siswa tematik terpadu kelas IV Sekolah Dasar tema Indahnya Kebersamaan untuk mengetahui nilai-nilai karakter yang harus ditanamkan pada siswa sudah benar-benar dikembangkan dan tidak ada yang terlewat

\section{METODE}

Pendekatan yang digunakan dalam penelitian ini adalah pendekatan kualitatif. Menurut Sukmadinata (2009: 60) penelitian kualitatif mempunyai dua tujuan utama yaitu, pertama menggambarkan dan mengungkap (to describe and explore) dan kedua menggambarkan dan menjelaskan (to describe and explain). Sehingga dengan pendekatan kualitatif, peneliti dapat memperoleh gambaran dan pemahaman mengenai nilai-nilai karakter yang terdapat pada buku siswa tema Indahnya Kebersamaan kelas IV Sekolah Dasar. Jenis penelitian yang digunakan adalah studi pustaka atau penelitian pustaka. Jenis penelitian studi pustaka ini digunakan untuk meneliti informasi tertulis yaitu nilai-nilai karakter yang terdapat pada buku siswa tema Indahnya Kebersamaan kelas IV Sekolah Dasar yang diterbitkan oleh Kemdikbud.

Sumber data dalam penelitian ini berupa buku siswa tema Indahnya Kebersamaan kelas IV Sekolah Dasar, sesuai dengan objek penelitian yang dikaji yaitu dokumen. Buku tersebut digunakan untuk mendapatkan data tentang nilai-nilai karakter sesuai dengan Standar Isi Kurikulum 2013. Pada penelitian ini berdasarkan studi pustaka ini, peneliti menggunakan metode dokumentasi. Dalam hal ini, Arikunto (2010:274) menyatakan bahwa "metode dokumentasi digunakan untuk mencari data mengenai hal-hal atau variabel yang berdasarkan catatan, transkip, buku, surat kabar, majalah, prasasti, notulen rapat, agenda dan sebagainya”. Penelitian ini yang digunakan sebagai sumber data untuk bahan analisis adalah buku siswa tema Indahnya
Kebersamaan kelas IV Sekolah Dasar yang diterbitkan oleh Kemdikbud.

Instrumen yang digunakan adalah lembar perekam data pada lampiran. Arikunto (2010:203) menyatakan bahwa lembar perekam data merupakan alat yang digunakan untuk mengumpulkan data analisis yang berbentuk tabel matrikulasi. Tabel tersebut diisi oleh peneliti dengan memasukkan kode, temuan data (nilai-nilai karakter), deskripsi terhadap temuan data (alasan mengapa termasuk $\mathrm{A} / \mathrm{B} / \mathrm{C} / \mathrm{D} / \mathrm{E} / \mathrm{F} / \mathrm{G})$, tafsiran data serta memilah pertanyaan bacaan tersebut termasuk $\mathrm{A} / \mathrm{B} / \mathrm{C} /$ $\mathrm{D} / \mathrm{E} / \mathrm{F} / \mathrm{G}$. Lembar perekam data akan digunakan untuk menganalisis nilai-nilai karakter pada buku siswa tema Indahnya Kebersamaan kelas IV Sekolah Dasar.

Tahapan analisis data yang digunakan dalam penelitian ini adalah analisis data kualitatif, mengikuti konsep yang diberikan oleh Miles \& Huberman (dalam Sugiyono, 2014: 337), yaitu (1) reduksi data (data reduction); (2) paparan data (data display); (3) penarikan kesimpulan dan verifikasi (Conclusion drawing/verifying). Kehadiran peneliti dalam penelitian ini adalah sebagai pelaksana penelitian. Peneliti melakukan penelitian mulai dari merencanakan, mengumpulkan data, menganalisis data, menginterprestasikan data, menarik kesimpulan, hingga melaporkan hasil penelitian. Penelitian ini tidak mengambil lokasi khusus karena dalam penelitian yang dikaji adalah dokumen berupa buku siswa tema Indahnya Kebersamaan kelas IV Sekolah Dasar terbitan Kemdikbud tahun 2016.

\section{HASIL}

Buku siswa tema Indahnya Kebersaman terdiri dari tiga subtema yaitu keberagaman budaya bangsaku, kebersamaan dalam keberagaman, dan bersyukur atas kebera-gaman. Berdasarkan hasil analisis dan perhitungan nilai-nilai karakter pada buku siswa tema Indahnya Kebersamaan kelas IV Sekolah Dasar muncul tujuh nilai-nilai karakter yaitu, religius, jujur, disiplin, santun, percaya diri, peduli, dan tanggung jawab. Persentase keragaman 
nilai karakter dan jumlah kemunculan nilai karakter tersebut dipaparkan secara singkat sebagai berikut.

Berdasarkan pada tabel 1.1 , persentase keragaman nilai karakter yang termasuk dalam kategori cukup yaitu karakter religius (28\%), karakter percaya diri $(27,9 \%)$, dan karakter peduli (20\%). Persentase keragaman nilai karakter yang termasuk dalam kategori sangat kurang yaitu karakter jujur (6,9\%), karakter disiplin $(3,7)$, karakter santun $(9 \%)$, dan karakter tanggung jawab (4,5\%).

Berdasarkan pada tabel 1.1, jumlah kemunculan nilai karakter yang termasuk dalam kategori sangat banyak yaitu karakter religius (98 kali), karakter percaya diri (97 kali), dan karakter peduli (69 kali). Jumlah kemunculan nilai karakter yang termasuk dalam kategori cukup yaitu karakter jujur (24 kali), dan karakter santun (31 kali). Jumlah kemunculan nilai karakter yang termasuk dalam kategori sedikit yaitu karakter disiplin (13 kali), dan karakter tanggung jawab (16 kali).

\section{PEMBAHASAN}

Pengembangan Nilai-Nilai Karakter pada Buku Siswa Tema Indahnya Kebersamaan

Berdasarkan hasil analisis pada buku siswa tema Indahnya Kebersamaan kelas IV Sekolah Dasar, penanaman nilai-nilai karakter sudah sesuai dengan Permendikbud No. 21 Tahun 2016 tentang Standar Isi Kurikulum 2013 untuk sekolah dasar dan menengah. Buku ajar yang baik hendaknya dapat mengembangkan dan memantapkan nilai- nilai yang berlaku dalam masyarakat setempat (Tarigan \& Tarigan, 2009: 23). Bagian buku yang mengembangkan nilai-nilai karakter yaitu pada bagian materi pembelajaran dan aktivitas pembelajaran berupa materi, gambar, petunjuk kerja, pertanyaan, dan aktivitas kelompok. Pengembangan nilai-nilai karakter tersebut disesuaikan dengan materi pengetahuan dan keterampilan yang akan diberikan.

Muatan karakter religius pada buku siswa tema Indahnya Kebersamaan sudah mengembangkan semua indikator pada karakter religius yaitu A1 (berdoa, bersyukur, dan beribadah), A2 (toleran terhadap pemeluk agama lain), dan A3 (menghargai keberagaman/perbedaan). Semua muatan karakter religius sudah sesuai dengan deskripsi karakter religius oleh Mendiknas (2010:9) yaitu "Sikap dan perilaku yang patuh dalam melaksanakan ajaran agama yang dianutnya, toleran terhadap pelaksanaan ibadah agama lain, dan hidup rukun dengan pemeluk agama lain". Karakter religius yang dikembangkan pada diri siswa sebagai upaya untuk menjadikan kehidupannya menjadi baik dan tidak menyimpang dari nilai-nilai agama yang berlaku. Hal tersebut sejalan dengan pendapat Azzet (2011:88) bahwa "Apabila seseorang mempunyai karakter yang baik terkait dengan Tuhan Yang Mahakuasa, seluruh kehidupannya akan menjadi menjadi baik".

Muatan karakter yang di dalamnya terdapat kegiatan menghias drum bekas untuk dijadikan tempat sampah. Dalam proses menghias tersebut dapat di masukkan kalimat/ gambar tentang pinjam-meminjam alat untuk

Tabel 1 Persentase Keragaman Nilai Karakter dan Jumlah Kemunculan Nilai Karakter

\begin{tabular}{llclcl}
\hline No & Nilai Karakter & $\begin{array}{c}\text { Persentase } \\
\text { Keragaman } \\
\text { Nilai Karakter }\end{array}$ & Kategori & $\begin{array}{c}\text { Jumlah Nilai } \\
\text { Karakter } \\
\text { yang Muncul }\end{array}$ & Kategori \\
\hline 1. & Religius & $28 \%$ & Cukup & 98 & Sangat Banyak \\
2. & Jujur & $6,9 \%$ & Sangat Kurang & 24 & Cukup \\
3. & Disiplin & $3,7 \%$ & Sangat Kurang & 13 & Sedikit \\
4. & Santun & $9 \%$ & Sangat Kurang & 31 & Cukup \\
5. & Percaya Diri & $27,9 \%$ & Cukup & 97 & Sangat Banyak \\
6. & Peduli & $20 \%$ & Cukup & 69 & Sangat Banyak \\
7. & Tanggung Jawab & $4,5 \%$ & Sangat Kurang & 16 & Sedikit \\
\hline \multicolumn{7}{c}{} \\
\hline
\end{tabular}


mengecat/menghias tong sampah yang dapat mengarahkan siswa untuk mengembalikan barang yang telah ia pinjam. Melalui alternatif tersebut dapat melengkapi muatan karakter jujur pada buku siswa tema Indahnya Kebersamaan kelas IV Sekolah Dasar. Dengan kejujuran akan terbentuk pribadi siswa yang dapat dipercaya dalam menyampaikan sesuatu. Azzet (2011:89) mengemukakan bahwa "tanpa adanya kejujuran, manusia sudah tidak mempunyai nilai kebaikan dihadapan orang lain". Oleh karena itu, penting untuk mengembangkan karakter jujur pada diri siswa supaya ia dapat dipercaya orang lain.

Muatan karakter disiplin pada buku siswa tema Indahnya Kebersamaan masih belum lengkap karena belum ada yang membahas atau mengarahkan siswa melakukan kegiatan tepat waktu (indikator C1). Indikator C1 (melakukan kegiatan tepat waktu) dapat dikembangkan pada lembar kerja atau aktivitas kelompok pada masing-masing subtema. Pengembangan tersebut dilakukan dengan cara memberikan batasan waktu untuk mengerjakan tugas atau kegiatan siswa. Dengan memberikan batasan waktu siswa tersebut dapat mengarahkan siswa untuk melakukan kegiatan tepat waktu. Melalui alternatif tersebut dapat melengkapi muatan karakter disiplin pada buku siswa tema Indahnya Kebersamaan kelas IV Sekolah Dasar. Disiplin merupakan karakter yang dimiliki oleh siswa yang taat terhadap aturan baik di sekolah, rumah, maupun masyarakat. Azzet (2011:90) mengemukakan bahwa "Tanpa disiplin yang baik, usaha yang dilakukan oleh seseorang juga sulit mencapai keberhasilan". Jadi, karakter disiplin sangat penting dikembangkan pada diri siswa agar dapat menjalani kehidupan dengan teratur dan mudah dalam meraih keberhasilan.

Muatan karakter santun pada buku siswa tema Indahnya Kebersamaan masih belum lengkap karena belum ada yang membahas atau mengarahkan siswa untuk berkata sopan, lemah lembut, dan ramah (indikator D2) serta memberi salam kepada orang lain (indikator D3). Indikator D2 (berkata sopan, lemah lembut, dan ramah) dapat dikembangkan dengan mengintegrasikannya ke dalam karakter percaya diri. Misalnya pada temuan berkode T1. ST1. PEM1. 7 yang berbunyi "Sampaikan hasilnya kepada gurumu", dapat ditambahkan indikator D2 dan menjadi "Sampaikan hasilnya kepada gurumu dengan bahasa yang baik dan sopan". Untuk indikator D3 (memberi salam) dapat di awal pembelajaran atau pada bagian kerjasama dengan orang tua dapat ditambahkan kalimat "sebelum kamu berangkat ke sekolah berilah salam kepada orangtuamu". Hal tersebut dapat dilakukan guna menanamkan rasa hormat dan santun dalam pergaulan pada diri siswa agar dapat menjalin kerjasama yang baik dengan orang lain. Pengembangan karakter santun pada diri siswa menurut Azzet (2011: 95) akan membuat diri siswa yang banyak disukai banyak orang dalam pergaulan, selalu menyenangkan dalam membangun sebuah hubungan, dan dapat membangun komunikasi dengan orang lain. Jadi, melalui pengembangan karakter santun pada siswa diharapkan membuat siswa dapat berhubungan dengan orang lain secara baik sesuai dengan aturan lingkungan yang ada.

Muatan karakter percaya diri pada buku siswa tema Indahnya Kebersamaan sudah lengkap karena sudah mengembangkan semua indikator pada karakter percaya diri yaitu E1 (berani menyampaikan pendapat), E2 (bertanya pada saat pembelajaran), E3 (berdiskusi dengan teman/guru/orang tua), E4 (menampilkan/menceritakan/menyampaikan di depan kelas), E5 (bernyanyi/ menari), dan E6 (menyimpulkan pelajaran). Muatan karakter percaya diri pada buku siswa tema Indahnya Kebersamaan sudah sesuai dengan deskripsi karakter percaya diri oleh Aqib \& Sujak (2011:7) yaitu "Sikap yakin akan kemampuan diri sendiri terhadap pemenuhan tercapainya setiap keinginan dan harapannya". Rasa percaya diri dibutuhkan oleh siswa untuk meraih keberhasilan dalam belajar atau meraih citacitanya. Hal tersebut sejalan dengan pendapat Aqib \& Sujak (2011:19) bahwa "Percaya pada 
diri sendiri adalah modal dasar untuk meraih kesuksesan dalam belajar". Pengembangan karakter pada siswa dilakukan agar siswa tidak ragu-ragu dalam melangkah agar ia dapat suskes meraih cita-citanya.

Muatan karakter peduli pada buku siswa tema Indahnya Kebersamaan masih belum lengkap karena belum ada yang membahas atau mengarahkan siswa untuk berbagi dengan sesama (indikator F2). Indikator F2 (berbagi dengan sesama) dapat dikembangkan pada subtema 3 bersyukur atas keberagaman. Dalam pembelajaran 4 pada bagian "Ayo Berdiskusi" terdapat cerita tentang Bu Mimin yang anaknya sedang sakit. Di dalam cerita tersebut Siti berdiskusi dengan teman-temannya untuk membantu Bu Mimin untuk menjaga kantin. Pada cerita tersebut dapat ditambahkan diskusi tentang mengumpulkan sumbangan untuk membantu anak Bu Mimin yang sedang sakit. Hal tersebut dapat mengarahkan siswa untuk berbagi dengan sesama. Melalui alternatif tersebut dapat melengkapi muatan karakter peduli pada buku siswa tema Indahnya Kebersamaan kelas IV Sekolah Dasar. Karakter peduli dikembangkan pada diri siswa agar ia memiliki rasa peduli terhadap sesama (sosial) dan lingkungan. Hal tersebut sejalan dengan pendapat Azzet (2011:97) yang mengemukakan bahwa "karakter peduli sosial dan lingkungan sangat perlu dibangun pada diri setiap anak didik". Memiliki karakter peduli sangat penting bagi siswa agar mereka lebih mudah bersosialisasi serta akan lebih dihargai.

Muatan karakter tanggung jawab pada buku siswa tema Indahnya Kebersamaan masih belum lengkap karena belum ada yang membahas atau mengarahkan siswa untuk melaksanakan piket (indikator G2). Indikator G2 (melaksanakan piket) dapat dikembangkan pada subtema 2 kebersamaan dalam keberagaman. Pada subtema tersebut banyak ditemukan nilai bekerjasama, dengan adanya nilai tesebut dapat dimasukkan juga tentang kerjasama dalam melaksanakan piket. Misalnya siswa diberikan tugas untuk melaksanakan piket bersama teman satu kelas atau diberikan tugas untuk menceritakan tentang kegiatan piket di kelasnya. Hal tersebut dapat mengarahkan siswa untuk melaksakan piket dan memiliki rasa tanggung jawab. Melalui alternatif tersebut dapat melengkapi muatan karakter tanggung jawab pada buku siswa tema Indahnya Kebersamaan kelas IV Sekolah Dasar. Dengan rasa tanggung jawab pada diri siswa akan mendorong siswa untuk senantiasa melaksakan hak dan kewajibannya sebagaimana yang semestinya ia lakukan. Prandiansyah (dalam Asmani, 2012:91) mengemukakan bahwa "Tanggung jawab merupakan kunci untuk meraih kesuksesan, seseorang yang mempunyai tanggung jawab akan mengeluarkan segala kemampuan terbaiknya untuk mememnuhi tanggung jawab tersebut". Jadi, pengembangan karakter tanggung jawab sangat penting dilakukan pada diri siswa agar mereka menjadi manusia yang bertanggung jawab dan meraih keberhasilan dalam belajar.

\section{PENUTUP}

\section{Kesimpulan}

Berdasarkan hasil penelitian dan pembahasan, maka dapat diperoleh kesimpulan sebagai berikut. Buku siswa tema Indahnya Kebersamaan kelas IV Sekolah Dasar memuat tujuh nilai karakter sesuai dengan Peraturan Menteri Pendidikan dan Kebudayaan No. 21 Tahun 2016 tentang Standar Isi Pendidikan Dasar dan Menengah. Ketujuh nilai karakter tersebut adalah religius, jujur, disiplin, santun, percaya diri, peduli, dan tanggung jawab. Pengembangan nilai karakter religius, percaya diri dan peduli pada buku buku siswa tema Indahnya Kebersamaan kelas IV Sekolah Dasar sudah dilakukan dengan cukup baik. Sedangkan pengembangan nilai karakter jujur, disiplin, santun, dan tanggung jawab pada buku buku siswa tema Indahnya Kebersamaan kelas IV Sekolah Dasar perlu ditambah dan dikembangkan. 


\section{Saran}

Berdasarkan kesimpulan di atas, dikemukkan beberapa saran bahwa bagi penyusun bahan/buku ajar agar dapat meninjau ulang dan melakukan perbaikan dan pengembangan terhadap nilai karakter yang masih sangat kurang yaitu nilai karakter jujur, disiplin, santun dan tanggung jawab yang terdapat pada buku ajar terutama pada buku siswa tema Indahnya Kebersamaan kelas IV Sekolah Dasar. Dalam hal ini nilai karakter tersebut harus dikembangkan secara merata dan seimbang agar dapat tertanam pada diri siswa sesuai dengan Standar Isi Kurikulum 2013. Bagi Guru, hendaknya perlu membaca secara lengkap isi buku siswa yang akan digunakan, khususnya pada bagian nilai-nilai karakter yang akan dikembangkan. Tujuannya agar kegiatan yang diberikan pada siswa benarbenar mengembangkan nilai karakter sesuai dengan fokus pengembangan karakter yang ada. Guru juga dapat menambah kegiatan untuk memunculkan dan mengembangkan nilai karakter jujur, disiplin, santun dan tanggung jawab. Bagi Peneliti Selanjutnya, diharapkan dapat menganalisis muatan nilai-nilai karakter pada tema-tema yang lain sehingga nilai-nilai karakter yang hendak dikembangkan dapat teridentifikasi dengan jelas.

\section{DAFTAR RUJUKAN}

Aqib, Zaenal dan Sujak. 2011. Panduan dan Aplikasi Pendidikan Karakter. Bandung: Yrama Widya.

Arikunto, Suharsimi. 2010. Prosedur Penelitian Suatu Pendekatan Praktik. Yogyakarta: PT Rineka Cipta.

Asmani, Jamal Ma'mur. 2012. Buku Panduan Internalisasi Pendidikan Karakter di Sekolah. Yogyakarta: Diva Press.
Azzet, Akhmad Muhaimin. 2011. Urgensi Pendidikan Karakter di Indonesia. Yogyakarta: Ar-Ruzz Media.

Kesuma, Dharma. 2011. Pendidikan Karakter Kajian Teori Dan Praktik Di Sekolah. Bandung: PT. Remaja Rosdakarya.

Mendiknas. 2010. Pengembangan Pendidikan Budaya Dan Karakter Bangsa. Jakarta: Kementrian Pendidikan Nasional, Badan Penelitian Dan Pengembangan Pusat Kurikulum.

Muslich, Masnur. 2010. Text Book Writing. Yogyakarta: Ar-Ruzz Media.

Muslich, Masnur. 2011. Pendidikan Karakter Menjawab Tantangan Krisis Multidimensional. Jakarta: PT. Bumi Aksara

Peraturan Menteri Pendidikan dan Kebudayaan Nomor 21 Tahun 2016 Tentang Standar Isi Pendidikan Dasar dan Menengah. Info Guru Indonesia, (Online), (http://www.guru-id.com), diakses 4 Januari 2017.

Peraturan Menteri Pendidikan Nasional Nomor 2 Tahun 2008 Tentang Buku. Badan Pembinaan Hukum Nasional, (Online), (http://www.bphn.go.id/), diakses 4 Januari 2017.

Sugiyono. 2014.Metode Penelitian Pendidikan Pendekatan Kuantitatif, Kualitatif, dan $R$ $\& D$. Bandung: Alfabeta.

Sukmadinata, Nana Syaodih. 2009. Metode Penelitian Pendidikan. Bandung: PT. Remaja Rosdakarya 